\title{
Detection of a novel single nucleotide polymorphism in IGF2 gene with a negative impact on egg production and body weight in Japanese quail (Coturnix japonica)
}

\author{
Dhafer A. Ali ${ }^{1}$, Mohammed Baqur S. Al-Shuhaib', Golzar Farhadi², Fadhil R. Al-Kafajy',
}

Tahreer M. Al-Thuwaini ${ }^{1}$ and Ali Esmailizadeh ${ }^{2 *}$ (1)

\begin{abstract}
Background: Insulin-like growth factor 2 (IGF2) is one of three hormones that share high structural similarity to insulin. It is involved in several insulin-like growth-regulating and mitogenic activities. This study was conducted to genotype the coding regions of the IGF2 gene in Japanese quail (Coturnix japonica) using PCR-SSCP-sequencing, and to assess the possible association of the polymorphism of these regions with the main egg production traits. A total of 240 female birds with an equal number of three Japanese quail populations (Brown or BR, Black or BL, and White or WT) were included in this study.

Results: All the genotyped regions exerted no heterogeneity in their sequences with one exception detected in the exon 2. In this locus, a novel single nucleotide polymorphism (SNP) was detected in which "A" was substituted with "G" at 81 position with a silent effect (p.F79=SNP) on IGF2 protein. Association analyses indicated a significant $(P<0.05)$ relation of this SNP with egg number (EN) and bird weight (BW) in the analyzed populations, in which the birds with AG genotype had lower EN and BW than those with AA genotype. The p.F79=SNP was largely detected in the WT line than the other two lines.

Conclusion: The detected p.F79=SNP has a highly negative effect on EN and BW in Japanese quail. Thus, the implementation of the variations of the IGF2 gene can be a useful marker in the marker-assisted selection of Japanese quail. This is the first report to describe IGF2 gene variations in Japanese quail, which strongly suggests raising the birds from the BR line with AA genotype when breeders desire to raise Japanese quail for large-scale egg production.
\end{abstract}

Keywords: Eggs production, Gene variation, IGF2, Japanese quails

\section{Background}

Japanese quails (Coturnix japonica) are the smallest farmed avian species with increasing profitable avenue as an alternative source for meat and eggs. These small-tomedium-sized birds belong to the same family of chicken and pheasant (Phasianidae) and have considerable

\footnotetext{
*Correspondence: aliesmaili@uk.ac.ir

2 Department of Animal Science, Faculty of Agriculture, Shahid Bahonar University of Kerman, Kerman, PB 76169-133, Iran

Full list of author information is available at the end of the article
}

similarities in physical characteristics and behavior [1]. However, these hardy birds characterize with more advantages than chickens, such as their substantial capacity to benefit from food, its resistance to many poultry diseases that invade chickens, low feed intake, and high reproductive proportions [2]. For these reasons, these birds are increasingly raised for producing both eggs and meats and as a laboratory animal model for multiple areas of scientific inquiries [3]. It is well-known that Japanese quails have achieved considerable importance in the 
specialty markets among agricultural species due to the unique flavor and high nutritional value of their meat and eggs $[4,5]$. However, several strategies of quails breeding have still been out of focus since the breeding of these is being challenged with decreased and unbalanced productivity. Therefore, the issues of selecting the most favorable quail populations for egg production are mandatory. So that, several candidate genes have been selected and considered as a basis for market-associated selection and their association with the main productive traits has been analyzed [6,7]. In addition, a number of genomic regions linked to the production traits in Japanese quail have been identified using linkage analyses [8-11]. One of these highly interesting candidates is the IGF2 gene (gene ID; 107314538). Due to multiple growth regulating activities attributed to this crucial insulin-similar gene, it can be considered as one of the major candidates for breeding improvements in birds. It consists of four exons and three introns within chromosome number 5 in quails (NCBI Reference Sequence: NC_029520.1). The expressed product of the IGF2 gene is the insulin growth factor 2 (IGF2), which is composed of 224 amino acids that share remarkable structural similarities with insulin (NCBI Reference Sequence: XP_015719328.1). IGF2 has a wide range of activities in controlling growth and development, such as cell growth promotion, survival control, migration, and differentiation via its corresponding IGF receptor [12]. It has been well established that this gene is involved in the stimulation of mitotic responses, and its knockout in mice leads to a significant reduction in body weight [13]. In birds, the versatile roles of IGF2 in controlling growth rate, lipid metabolism, and body composition have been documented [14]. The association of IGF2 gene polymorphism with growth and production traits has extensively been described in chickens [15]. Despite the beneficial information obtained from these association studies, this possible association has not been described in Japanese quail. Therefore, the present study aimed to investigate the association between IGF2 gene polymorphism with egg production traits in three domesticated lines of Japanese quail. According to our knowledge, this study is the first one to analyze the genetic variation of the IGF2 gene in Japanese quail.

\section{Methods}

\section{Japanese quail lines}

Initially, 1200 eggs of Japanese quail (Coturnix japon$i c a$ ) were included in the study. Equal total number of these eggs were collected from three lines of quails; Brown (BR) line $(n=400)$, Black (BL) $(n=400)$, and White (WT) line $(n=400)$. Eggs were incubated and hatched using the hatching guidelines recommended by Romao et al. [16]. The living conditions, housing, feeding, temperature, sex determination were performed according to Al-Kafajy et al. [17]. Once quails get sexual maturity, males were excluded from the study, and only females were retained and individually maintained in laying cages. Subsequently, the egg number (EN), egg weight $(\mathrm{EW})$, and birds weight (BW) were recorded on a total of 240 female birds from three lines of Japanese quail, BL ( $n$ $80)$, BR ( $n$ 80), and WT ( $n$ 80). All EN, EW, and BW traits were recorded weekly, starting from the proposed sexual maturity week (week 6) until week 12.

\section{Genomic DNA isolation}

One drop of peripheral blood was collected from the wing vein of each female quail. Genomic DNA was extracted from all 240 birds using a manual salting out procedure [18]. The quantity and quality were described in birds [19]. The genomic DNA integrity was visualized by direct electrophoresis on ethidium bromide pre-stained $0.08 \%$ agarose evaluated using a Nanodrop spectrophotometric method (Biodrop, $\mu$ LITE, UK).

\section{Polymerase chain reaction}

Four PCR fragments were designed using NCBI PrimerBLAST software [20]. The main designing approach for these four primers pairs was made to cover all four coding regions of the IGF2 gene in such a way each PCR amplicon would represent one specified exon. The lyophilized oligonucleotides were purchased from Bioneer (Daejeon, South Korea). The PCR amplification reactions were performed using Bioneer PCR premix. The optimum amplification conditions for the four designed amplicons were empirically determined using a gradient PCR as described in Table 1. Standard PCR experiments were performed on PCR thermocycler (Nexus, Eppendorf, Hamburg, Germany). The amplification protocol was initiated by one cycle of denaturation at $94^{\circ} \mathrm{C}$ for 4 min, followed by 30 cycles of denaturation at $94^{\circ} \mathrm{C}$ for 30 $\mathrm{s}$, annealing for $45 \mathrm{~s}$, and elongation at $74^{\circ} \mathrm{C}$ for $45 \mathrm{~s}$, and was concluded with a final extension at $72^{\circ} \mathrm{C}$ for $5 \mathrm{~min}$. PCR amplicons were verified by electrophoresis on $1.5 \%$ agarose gel.

\section{Single-strand conformation polymorphism (SSCP)}

SSCP experiments were performed using a rapid high voltage approach [21], with several modifications. Briefly, each PCR amplicon was treated with an equal volume of SSCP denaturing-loading buffer (95\% formamide, 0.05\% xylene cyanol, $0.05 \%$ bromophenol blue, and $20 \mathrm{mM}$ EDTA, pH 8). After denaturation for $7 \mathrm{~min}, 2 \mu \mathrm{l}$ of PCR amplicons were immediately placed on ice and frozen for about $10 \mathrm{~min}$. Subsequently, $2 \mu \mathrm{l}$ of samples were loaded on neutral polyacrylamide gel $(0.1 \mathrm{~mm}$ thickness, $10 \mathrm{~cm}$ length, and $20 \mathrm{~cm}$ width). Electrophoresis conditions 
Table 1 The oligonucleotide primer sets designed for the amplification of the IGF2 in three populations of Japanese quails. The present annotations of this study variants were based on GenBank accession number NC_029520.1

\begin{tabular}{|c|c|c|c|c|c|}
\hline Set & Primer code & Primer sequence $\left(5^{\prime} \rightarrow 3^{\prime}\right)$ & Locus & Length & Annealing temp. \\
\hline \multirow[t]{2}{*}{1} & IGF2,exo1-F & GGTCCCTCTAGTGACACGC & Exon 1 & 365 bp & NA \\
\hline & IGF2,exo1-R & CAAAGCGAGGAGAGAGAGCC & & & \\
\hline \multirow[t]{2}{*}{2} & IGF2,exo2-F & TTGGCATAGCATGAGGTGGG & Exon 2 & 232 bp & $61.0^{\circ} \mathrm{C}$ \\
\hline & IGF2,exo2-R & ATGGCTTCTTTTCCCCAGGTG & & & \\
\hline \multirow[t]{2}{*}{3} & IGF2,exo3-F & CTACCTTGTTGAGGGCTGGG & Exon 3 & 236 bp & $60.7^{\circ} \mathrm{C}$ \\
\hline & IGF2,exo3-R & TGGGTAAAGGGTGACGAAGC & & & \\
\hline \multirow[t]{2}{*}{4} & IGF2,exo4-F & CCGGCTGGTCACAGTTCATT & Exon 4 & 277 bp & $59.8^{\circ} \mathrm{C}$ \\
\hline & IGF2,exo4-R & GTTGTTCTCCCTTCCCCAGG & & & \\
\hline
\end{tabular}

were optimized according to details described in Table 2. Gels were fixed and stained according to the protocol of Byun et al. [22].

\section{DNA sequencing}

Each detected genotype on the SSCP gel was subsequently exposed to sequencing reaction from both termini according to instructions of Macrogen laboratories (Macrogen, Geumchen, Seoul, Korea). The referring database of the IGF2 nucleic acid sequences was retrieved (https://www.ncbi.nlm.nih.gov). The sequenced SSCP genotypes were visualized and annotated by BioEdit ver, 7.1. (DNASTAR, Madison). The amino acid reading frames of the SSCP variants were determined using the Expasy translate server (http://web.expasy.org/ translate/). Each detected variant was visualized using SnapGene Viewer ver. 4.0.4 (http://www.snapgene.com). Only clear electropherograms were considered in the observed variations in comparison with their retrieved corresponding references of the IGF2 sequences (GenBank accession number NC_029520.1). The appropriate reading frame of each observed variant was aligned with its corresponding reference sequences within the IGF2 protein using the UniProtKB server (http://www.uniprot. $\operatorname{org} /$ align/).

\section{Genetic diversity analyses}

The assessment of the genetic polymorphism of the IGF2 gene variants was performed by calculating allele and genotype frequencies, observed heterozygosity $(\mathrm{Ho})$, expected heterozygosity $(\mathrm{He})$, and the effective number of alleles $(\mathrm{Ne})$ were performed using PopGen32 software, v. 1.31 [23]. Chai-squared test $\left(\chi^{2}\right)$ was also calculated to verify the possible deviation from Hardy-Weinberg Equilibrium (HWE) expectations for the distribution of genotypes. The polymorphism information content (PIC) was computed using the following formula [24].

$$
\text { PIC }=1-\sum_{i=1}^{m} p_{i}^{2}-\sum_{i=1}^{m-1} \sum_{j=i+1}^{m} 2 p_{i}^{2} p_{j}^{2}
$$

where $p i$ and $p j$ are the frequencies of the $i$ th and $j$ th allele, respectively, and $\mathrm{m}$ is the number of alleles.

\section{Association analyses}

Statistical analyses to determine the significance of the lines and IGF2 genotypic effects were analyzed by ANOVA-repeated measures (GLM procedure of SPSS, $v$ 23), in which the following model was used;

$$
Y_{i j k}=\mu+L_{j}+G_{k}+(L G)_{j k}+p_{j}+\gamma_{i j}++\eta_{i k}+e_{i j k}
$$

where $\mu$ is the overall mean, $L_{j}$ is the main effect of lines to $\left(\sum L_{j}=0\right), G_{k}$ is the main effect of genotype to ( $\left.\sum G_{k}=0\right),(L G){ }_{j k}$ is the interaction effect, $p_{j}$ is the main effect of subjects $N\left(0, \sigma^{2}{ }_{i}\right), \gamma_{i j}$ is the interaction effect of subjects and lines $\sim N\left(0 ; \sigma^{2}{ }_{i j}\right), \eta_{i k}$ is the interaction effect

Table 2 SSCP electrophoresis conditions of the amplicons of the IGF2 gene in three lines of Japanese quails. All PCR amplicons were electrophoresed on $0.1 \mathrm{~mm}$ thickness of $10 \times 20(\mathrm{~L} \times \mathrm{W}) \mathrm{cm}$ diameters polyacrylamide gels

\begin{tabular}{lllllll}
\hline Set & Amplicons & Gel concentration & $\begin{array}{l}\text { Running } \\
\text { temperature }\end{array}$ & Running time & Running voltage & Running amperage \\
\hline 1 & IGF2,exo2 & $8 \%$ & $16^{\circ} \mathrm{C}$ & $4.0 \mathrm{hr}$ & $210 \mathrm{~V}$ & $100 \mathrm{~mA}$ \\
2 & IGF2,exo3 & $10 \%$ & $18^{\circ} \mathrm{C}$ & $4.5 \mathrm{hr}$ & $200 \mathrm{~V}$ & $100 \mathrm{~mA}$ \\
3 & IGF2,exO4 & $8 \%$ & $20^{\circ} \mathrm{C}$ & $4.5 \mathrm{hr}$ & $200 \mathrm{~V}$ & $105 \mathrm{~mA}$ \\
\hline
\end{tabular}


of subjects and genotype $\sim N\left(0 ; \sigma^{2}{ }_{\mathrm{ik}}\right)$ and $e_{i j \mathrm{k}}$ is random error assumed $e_{i j k} \sim N\left(0 ; \sigma^{2}\right)$. Means of the significant main factors were compared using the Tukey test. $P$-values of less than 0.05 were considered statistically significant for all comparisons.

\section{Results}

\section{Genotyping analyses}

All the coding regions of the IGF2 gene, as well as their flanking regions, were screened by designing four specific PCR primers (Fig. 1A). Unfortunately, the PCR experiments of the first PCR amplicons designed to specifically amplify the exon 1 were tuned to be problematic since no specific results were detected. The other three amplicons of exon 2, exon 3, and exon 4 amplicons showed specific PCR products, of $232 \mathrm{bp}, 236 \mathrm{bp}$, and $277 \mathrm{bp}$, respectively. Concerning both exon 3 and exon 4 amplicons, no heterogeneity was observed after being analyzed by PCR-SSCP gels. Considering exon 2 amplicons, two PCRSSCP patterns were detected, one pattern with two bands and the other one with three bands (Fig. 1B). Sequencing reactions confirmed this heterogeneity by detecting a homozygous A/A electropherograms at the 81th position in the two bands pattern and a heterogeneous A/G electropherograms at the same position in the three bands pattern (Fig. 1C). The novelty of the observed A81G SNP was confirmed by Ensembl browser 9. Both detected SSCP genotypes were assigned AA and AG for the homogenous and heterogeneous status of each genotype. The observed AA and AG genotypes were respectively deposited in the NCBI-bankit database under the accession numbers (MT193259 and MT193260). It was observed that this SNP was positioned in the Phe79 within the IGF2 protein. The silent effect $(\mathrm{p} . \mathrm{F} 79=)$ was determined by expasy translate and UniprotKB servers, respectively (Fig. 1D).

\section{Genetic diversity and association analyses}

Concerning the BR line, the most abundant genotype was AA, which was predominantly observed in this studied population with a total frequency of $0.76(n=61)$. The highly dominant AA genotype was followed by the AG genotype, which was detected with a total frequency of $0.24(n=19)$. The high percentage of AA genotype was reduced in the BL line, which was detected in lower frequency $(0.65, n=52)$, with an increased ratio of AG

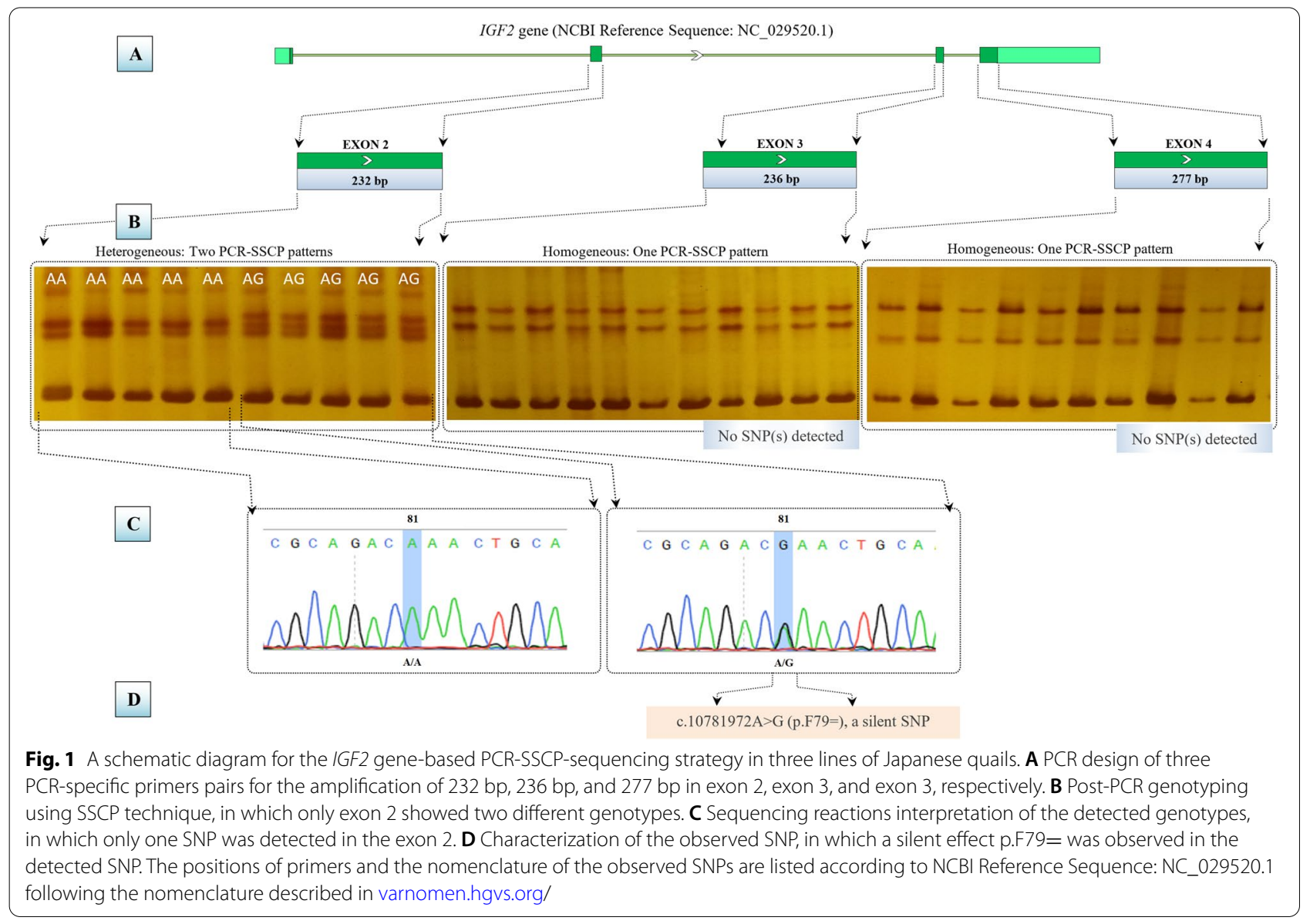


genotype $(0.35, n=28)$. In contrast to BR and BL lines, the lowest frequency of AA genotype $(0.34, n=27)$ was observed in the WT line, with the advent predominance of the AG genotype $(0.66, n=53)$. This sort of genotype distribution ranged from low in the BR line (PIC = $0.188)$, intermediate in the $\mathrm{BL}$ line $(\mathrm{PIC}=0.251)$, to high in the WT line (PIC $=0.344$ ) (Table 3). However, the values of $\mathrm{Ho}, \mathrm{He}, \mathrm{Ne}$, and PIC in WT line at p.F79= SNP locus were higher than that of BL and BR breed, respectively, which implied that the polymorphism and genetic variation of WT breed were higher than that found in BL and BR populations, respectively. However, the Chai square tests showed that the polymorphism of the IGF2 gene in all three studied birds populations showed significant deviation from the Hardy Weinberg equilibrium $(P<0.05)$.

Association analyses results showed a significant $(P<$ $0.05)$ contribution of lines of birds (BR, BL, and WT) and the two detected genotypes (AA and AG genotype) of the IGF2 gene. This line/genotype interaction was continuously observed in two measured production traits at all time intervals. Line of birds and genotype of IGF2 were both significantly $(P<0.05)$ associated with EN and BW in all recorded egg production weeks (Table 4). Differences between BR, BL, and WT lines were statistically significant $(P<0.05)$ for EN and BW traits, since birds with AA genotype showed higher EN and BW traits than birds with AG genotype. This observation implied that the silent p.F79= SNP of the AG genotype exerted a negative significant $(P<0.05)$ association with $\mathrm{EN}$ and $\mathrm{BW}$ traits. The remarkable differences in the frequency of AA genotype (0.76) than AG genotype had given the BR line advent superiority in terms of egg production traits than $\mathrm{BL}$ and WT lines, respectively. However, no significant $(P<0.05)$ association between line/genotype factors was observed in correlation with EW in the entire measurement period. Nevertheless, a clear tendency of birds with $\mathrm{BR}$ lines to exhibit more values than the BL and WT lines respectively was observed in almost all measured EW. The same tendency of birds with AA genotype to exhibit higher values in EW than birds with AG genotypes was also observed. However, these differences were not reached the significant thresholds in all recorded weeks (Table 5).

\section{Discussion}

Several reasons led us to conduct the present study on the IGF2 gene in Japanese quails. It was reported that IGF2 polypeptide is a member within the somatotropic axis with advent ability to regulate growth and development, and thus egg production trait in several breeds of chickens [15]. Besides, polymorphism in the IGF2 gene was tightly linked with egg production traits in Muscovy ducks [25]. These observations may refer to a considerable correlation between IGF2 function and egg production. Likewise, several candidate genes are increasingly being reported to be associated with production traits in quails [26-28]. For this reason, the genetic variations within this critical gene may bring several alterations for productive performance in quail populations.

After screening Japanese quails to investigate the IGF2 polymorphism, two genotypes were detected, AA genotype and AG genotype. One silent, p.F79=SNP was detected in birds with AG genotype. Since birds with AA genotype were characterized with better production traits than those with AG genotype, obvious negative impacts of the p.F71 $=$ SNP on these traits were observed. This observation entails a remarkable association between this SNP and the low values of EN, BW, and EW to a little extent. However, this finding may signify a considerable importance for this silent SNP as a causative factor for metabolic alterations [29]. Though no missense SNP was detected in all the investigated quail's population, the present study detected a crucial silent SNP, which was found to be associated with low productivity in quails. This finding may add a further layer of confirmation on the recent understanding of the critical functionality of the silent SNP in various metabolic activities [30]. Though there is no accurate mechanism to explain how silent SNP may have such a functional impact [31], it could change substrate specificity which may lead to alternative protein kinetics [32].

Table 3 Genotype and allele frequencies and genetic diversity variables for p.F79= SNP locus of the IGF2 gene in three lines of Japanese quails

\begin{tabular}{|c|c|c|c|c|c|c|c|c|c|}
\hline \multirow[b]{2}{*}{ Line } & \multicolumn{2}{|c|}{ Genotype frequencies $(n)$} & \multicolumn{2}{|c|}{ Allele frequencies } & \multirow[b]{2}{*}{ Ho } & \multirow[b]{2}{*}{$\mathrm{He}$} & \multirow[b]{2}{*}{$\mathrm{Ne}$} & \multirow[b]{2}{*}{$x^{2}$} & \multirow[b]{2}{*}{ PIC } \\
\hline & AA & AG & A & G & & & & & \\
\hline$B R$ & $0.76(n=61)$ & $0.24(n=19)$ & 0.8812 & 0.1187 & 0.2375 & 0.2106 & 0.2093 & 1.368693 & 0.188 \\
\hline$B L$ & $0.65(n=52)$ & $0.35(n=28)$ & 0.8250 & 0.1750 & 0.3500 & 0.2906 & 0.2888 & 3.453851 & 0.251 \\
\hline WT & $0.34(n=27)$ & $0.66(n=53)$ & 0.6687 & 0.3312 & 0.6625 & 0.4458 & 0.4430 & 19.196262 & 0.344 \\
\hline
\end{tabular}

$n$ number of samples, $x^{2}$ chi-square, Ho observed heterozygosity, He expected heterozygosity, Ne effective allele number, PIC polymorphism information content. All Chi-square tests have one degree of freedom and are within the significance level $P<0.05$ 
Table 4 Least square means ( \pm SE) of interaction effects of AA and AG genotypes on egg production traits in three lines of Japanese quails

\begin{tabular}{|c|c|c|c|c|c|c|c|}
\hline \multirow[t]{2}{*}{ Time (week) } & \multirow[t]{2}{*}{ Trait } & \multicolumn{2}{|l|}{ BR } & \multicolumn{2}{|l|}{$B L$} & \multicolumn{2}{|l|}{ WT } \\
\hline & & AA & AG & AA & AG & AA & AG \\
\hline \multirow[t]{3}{*}{ Week 6} & EN & $49.617 \pm 3.541^{\mathrm{Aa}}$ & $40.563 \pm 2.529^{B C}$ & $45.096 \pm 1.283^{\mathrm{Aab}}$ & $39.871 \pm 2.548^{B C}$ & $42.134 \pm 3.567^{\mathrm{Ab}}$ & $39.096 \pm 2.522^{B C}$ \\
\hline & EW & $9.883 \pm 0.545$ & $9.794 \pm 0.504$ & $9.605 \pm 0.559$ & $9.489 \pm 0.502$ & $9.526 \pm 0.499$ & $9.403 \pm 0.550$ \\
\hline & BW & $218.091 \pm 10.551^{\mathrm{Aa}}$ & $211.094 \pm 11.504^{\mathrm{Bb}}$ & $211.265 \pm 11.263^{\mathrm{Ab}}$ & $206.389 \pm 12.502^{B a b}$ & $204.126 \pm 13.499 \mathrm{Aab}$ & $200.103 \pm 11.550^{B C}$ \\
\hline \multirow[t]{3}{*}{ Week 7} & EN & $59.654 \pm 2.659^{\mathrm{Aa}}$ & $55.694 \pm 3.504^{B ~ b ~}$ & $55.742 \pm 2.535^{\mathrm{Ab}}$ & $52.682 \pm 4.541 \mathrm{~B} \mathrm{ab}$ & $51.400 \pm 5.518 \mathrm{Aab}$ & $49.417 \pm 3.541^{B C}$ \\
\hline & EW & $10.887 \pm 0.558$ & $10.652 \pm 0.536$ & $10.607 \pm 0.556$ & $10.489 \pm 0.502$ & $10.430 \pm 0.520$ & $10.401 \pm 0.540$ \\
\hline & BW & $224.225 \pm 13.809 \mathrm{Aa}$ & $214.294 \pm 10.504^{B ~ b ~}$ & $220.409 \pm 9.985^{\mathrm{Aa}}$ & $210.489 \pm 8.502^{B C}$ & $215.503 \pm 12.513^{\mathrm{Ab}}$ & $210.515 \pm 10.543^{B C}$ \\
\hline \multirow[t]{3}{*}{ Week 8} & EN & $75.151 \pm 1.301^{\mathrm{Aa}}$ & $70.294 \pm 2.504^{B b}$ & $68.892 \pm 2.591$ Аab & $62.878 \pm 3.535^{B C}$ & $65.557 \pm 2.185^{\mathrm{Aab}}$ & $61.198 \pm 1.618^{B C}$ \\
\hline & EW & $10.995 \pm 0.552$ & $10.763 \pm 0.533$ & $10.996 \pm 0.558$ & $10.703 \pm 0.511$ & $10.726 \pm 0.523$ & $10.603 \pm 0.539$ \\
\hline & BW & $229.621 \pm 10.523 \mathrm{Aa}$ & $219.794 \pm 11.504^{\mathrm{Bb}}$ & $219.371 \pm 10.226^{A b}$ & $210.489 \pm 8.489^{B C}$ & $212.526 \pm 7.499^{A C}$ & $208.503 \pm 9.503^{B C}$ \\
\hline \multirow[t]{3}{*}{ Week 9} & EN & $69.261 \pm 1.232^{\mathrm{Aa}}$ & $65.394 \pm 3.504^{\mathrm{Bb}}$ & $64.590 \pm 2.586^{\mathrm{Ab}}$ & $61.582 \pm 2.546^{B C}$ & $62.603 \pm 3.503 \mathrm{Ac}$ & $60.615 \pm 5.548^{B C}$ \\
\hline & EW & $11.888 \pm 0.554$ & $11.794 \pm 0.509$ & $11.701 \pm 1.566$ & $11.689 \pm 1.502$ & $11.834 \pm 0.492$ & $11.600 \pm 0.552$ \\
\hline & BW & $226.259 \pm 10.638 \mathrm{Aa}$ & $216.294 \pm 9.504^{\text {В b }}$ & $224.257 \pm 12.693 \mathrm{Aa}$ & $214.589 \pm 10.502^{\mathrm{Bb}}$ & $216.526 \pm 11.499^{A b}$ & $206.503 \pm 10.550^{B C}$ \\
\hline \multirow[t]{3}{*}{ Week 10} & EN & $72.869 \pm 1.805^{\mathrm{Aa}}$ & $67.136 \pm 2.553^{B b}$ & $66.515 \pm 3.833^{A b}$ & $63.385 \pm 2.542^{\mathrm{Bab}}$ & $62.007 \pm 3.465^{\mathrm{Aab}}$ & $59.013 \pm 2.564^{B C}$ \\
\hline & EW & $11.387 \pm 0.558$ & $11.194 \pm 0.504$ & $11.296 \pm 0.579$ & $11.289 \pm 0.502$ & $11.326 \pm 0.523$ & $11.103 \pm 0.539$ \\
\hline & BW & $230.656 \pm 11.335^{\mathrm{Aa}}$ & $228.494 \pm 10.504^{\text {B b }}$ & $226.588 \pm 13.184^{A b}$ & $220.989 \pm 12.502^{\mathrm{Bab}}$ & $219.326 \pm 10.499 \mathrm{Aab}$ & $209.303 \pm 9.550^{B C}$ \\
\hline \multirow[t]{3}{*}{ Week 11} & EN & $79.585 \pm 1.065^{\mathrm{Aa}}$ & $75.694 \pm 2.504^{B b}$ & $70.400 \pm 2.610^{\mathrm{Aab}}$ & $69.353 \pm 2.536^{\mathrm{Bab}}$ & $67.342 \pm 4.539^{\mathrm{Aab}}$ & $62.262 \pm 5.529^{B C}$ \\
\hline & EW & $11.987 \pm 0.558$ & $11.794 \pm 0.504$ & $11.605 \pm 0.559$ & $11.589 \pm 0.502$ & $11.626 \pm 0.499$ & $11.503 \pm 0.550$ \\
\hline & BW & $234.567 \pm 7.754^{\mathrm{Aa}}$ & $231.494 \pm 9.504^{\mathrm{B} \mathrm{a}}$ & $231.117 \pm 12.979^{\mathrm{Aa}}$ & $218.489 \pm 10.502^{\mathrm{B} \mathrm{a} \mathrm{b}}$ & $225.326 \pm 11.499^{\mathrm{Ab}}$ & $211.303 \pm 9.550^{B C}$ \\
\hline \multirow[t]{3}{*}{ Week 12} & EN & $79.182 \pm 3.087^{\mathrm{Aa}}$ & $74.294 \pm 2.504^{\text {B b }}$ & $71.625 \pm 3.083^{A b}$ & $69.775 \pm 3.537^{\mathrm{Bab}}$ & $68.973 \pm 2.519^{\mathrm{Aab}}$ & $62.030 \pm 4.540^{B C}$ \\
\hline & EW & $11.988 \pm 0.555$ & $11.694 \pm 0.504$ & $11.705 \pm 0.559$ & $11.589 \pm 0.502$ & $11.526 \pm 0.499$ & $11.503 \pm 0.550$ \\
\hline & BW & $233.030 \pm 6.626^{\mathrm{Aa}}$ & $230.036 \pm 5.553^{\mathrm{B} \mathrm{a}}$ & $230.198 \pm 10.480 \mathrm{Aa}$ & $218.471 \pm 8.482^{\mathrm{Bab}}$ & $223.026 \pm 10.499^{\mathrm{Ab}}$ & $213.003 \pm 7.550^{B C}$ \\
\hline
\end{tabular}

Values followed by different alphabets differ significantly

$A, B$ different capital letters indicate a significant difference in the genotypes within each classification $(P \leq 0.05)$.

${ }^{a, b}$ Different lowercase letters indicate a significant difference in lines within each classification $(P \leq 0.05)$

$E N$, EW, and BW refer to egg number, egg weight, and bird weight, respectively. Data expressed as means \pm SD

Apart from genotyping results, three lines of Japanese quails were investigated in this study, BR, WT, and WT. $\mathrm{BR}$ line showed higher egg production values than $\mathrm{BL}$ and WT lines respectively. In all measured production weeks, birds of BR line had shown higher values of EN and BW than both birds of BL and WT lines respectively. In agreement with our findings, Bagh et al [33] have also revealed the superiority of BR birds over other birds in terms of egg production traits. However, each selected line has been found to exhibit a unique association with egg production [17]. In addition to the observed differences in plumage color among BR, BL, and WT lines [34], it has been reported that each line is characterized by a different productive performance [35]. Due to these considerable differences among these lines, it is rational to explain clear intervention of all three lines as non-genetic factors alongside the observed genetic factors with the measured production traits in Japanese quails [36]. However, it is well established that production in birds is multifactorial and it could not be regulated by implicating only one factor, whether being based on genetic or non-genetic origin. Nevertheless, our conducted genetic diversity analyses indicated three distinct frequencies of the detected IGF2-based genotyping in the three investigated populations. BR line exhibited the lowest AG genotype and highest AA genotype frequencies among the other two populations. In contrast to BR line, WT line exhibited the opposite distribution of both AA and AG genotypes, while BL line showed moderate distributions of them. Statistical analyses indicated that birds having AG genotype exerted the lower EN and BW than those with the AA genotype. This observation signifies that the line with a higher frequency of AG genotype had lower egg production traits. Taking these data into account, it can be concluded that BR line is the most recommended population for egg production since it showed a lower frequency of AG genotype than both BL and WT lines respectively. Accordingly, the results of this study indicated that both genetic (AA and AG genotypes) and non-genetic (BR, BL, and WT lines) factors were not found to exhibit an independent effect on the measured productive performance in the investigated lines of 
Table 5 Least square means $( \pm S D$ ) of the main effects of AA and AG genotypes and lines on egg production traits in three lines of Japanese quails

\begin{tabular}{|c|c|c|c|c|c|c|}
\hline \multirow[t]{2}{*}{ Time (week) } & \multirow[t]{2}{*}{ Trait } & \multicolumn{3}{|l|}{ Line } & \multicolumn{2}{|l|}{ Genotype } \\
\hline & & BR & $\mathrm{BL}$ & WT & AA & AG \\
\hline \multirow[t]{3}{*}{ Week 6} & EN & $49.108 \pm 3.534^{\mathrm{a}}$ & $44.017 \pm 3.017^{a b}$ & $38.604 \pm 4.535^{b}$ & $47.512 \pm 4.940^{a}$ & $41.120 \pm 3.998^{b}$ \\
\hline & EW & $9.811 \pm 1.530$ & $9.700 \pm 1.537$ & $9.685 \pm 2.532$ & $9.760 \pm 0.529$ & $9.510 \pm 0.550$ \\
\hline & BW & $217.092 \pm 10.538^{a}$ & $211.308 \pm 11.058^{a b}$ & $204.111 \pm 10.530^{b}$ & $209.862 \pm 12.885^{a}$ & $200.472 \pm 13.634^{b}$ \\
\hline \multirow[t]{3}{*}{ Week 7} & EN & $59.664 \pm 5.623^{a}$ & $54.721 \pm 4.534^{\mathrm{ab}}$ & $51.411 \pm 4.530^{b}$ & $58.897 \pm 4.070^{\mathrm{a}}$ & $50.984 \pm 3.984^{b}$ \\
\hline & EW & $10.811 \pm 2.530$ & $10.601 \pm 1.535$ & $10.479 \pm 1.550$ & $10.242 \pm 0.528$ & $10.021 \pm 0.549$ \\
\hline & BW & $224.242 \pm 10.746^{a}$ & $222.437 \pm 10.845^{\mathrm{a}}$ & $215.511 \pm 10.530^{b}$ & $221.188 \pm 13.328^{a}$ & $211.576 \pm 13.549^{b}$ \\
\hline \multirow[t]{3}{*}{ Week 8} & EN & $70.185 \pm 3.163^{a}$ & $65.887 \pm 3.569^{a b}$ & $61.316 \pm 2.818^{b}$ & $69.487 \pm 4.377^{\mathrm{a}}$ & $61.117 \pm 3.713^{b}$ \\
\hline & EW & $10.787 \pm 0.545$ & $10.698 \pm 1.539$ & $10.611 \pm 1.530$ & $10.727 \pm 0.549$ & $10.662 \pm 0.529$ \\
\hline & BW & $229.661 \pm 11.354^{a}$ & $219.412 \pm 11.029^{a b}$ & $212.511 \pm 10.530^{b}$ & $222.639 \pm 16.817^{a}$ & $210.745 \pm 16.611^{b}$ \\
\hline \multirow[t]{3}{*}{ Week 9} & EN & $69.292 \pm 3.104^{\mathrm{a}}$ & $64.537 \pm 2.569^{a b}$ & $60.611 \pm 3.530^{b}$ & $67.804 \pm 4.106^{\mathrm{a}}$ & $61.554 \pm 3.398^{b}$ \\
\hline & EW & $11.990 \pm 0.541$ & $11.900 \pm 0.541$ & $11.811 \pm 0.530$ & $11.920 \pm 0.548$ & $11.871 \pm 0.532$ \\
\hline & BW & $226.267 \pm 10.607^{a}$ & $219.373 \pm 12.190^{a b}$ & $206.511 \pm 10.530^{b}$ & $221.851 \pm 17.592^{a}$ & $211.328 \pm 19.449^{b}$ \\
\hline \multirow[t]{3}{*}{ Week 10} & EN & $72.932 \pm 3.602^{\mathrm{a}}$ & $66.470 \pm 2.743^{a b}$ & $60.011 \pm 3.530^{b}$ & $69.006 \pm 5.747^{\mathrm{a}}$ & $61.791 \pm 4.353^{b}$ \\
\hline & EW & $11.098 \pm 0.543$ & $11.093 \pm 0.550$ & $11.011 \pm 0.530$ & $11.805 \pm 0.584$ & $11.003 \pm 0.572$ \\
\hline & BW & $230.728 \pm 12.582^{a}$ & $220.618 \pm 11.192^{a b}$ & $209.311 \pm 10.530^{b}$ & $226.241 \pm 17.932^{a}$ & $217.502 \pm 19.456^{b}$ \\
\hline \multirow[t]{3}{*}{ Week 11} & EN & $79.611 \pm 3.961^{\mathrm{a}}$ & $74.383 \pm 3.582^{a b}$ & $71.288 \pm 2.530^{b}$ & $76.571 \pm 3.840^{\mathrm{a}}$ & $69.920 \pm 3.593^{b}$ \\
\hline & EW & $11.988 \pm 0.543$ & $11.700 \pm 0.537$ & $11.611 \pm 0.530$ & $11.601 \pm 0.544$ & $11.498 \pm 0.523$ \\
\hline & BW & $231.247 \pm 12.418^{a}$ & $226.550 \pm 10.701^{a b}$ & $211.311 \pm 10.530^{b}$ & $225.427 \pm 17.309^{a}$ & $219.842 \pm 19.282^{b}$ \\
\hline \multirow[t]{3}{*}{ Week 12} & EN & $78.208 \pm 3.980^{\mathrm{a}}$ & $71.677 \pm 3.928^{a b}$ & $66.011 \pm 3.530^{b}$ & $76.479 \pm 4.763^{\mathrm{a}}$ & $69.699 \pm 4.775^{b}$ \\
\hline & EW & $11.990 \pm 0.541$ & $11.600 \pm 0.537$ & $11.411 \pm 0.530$ & $11.557 \pm 0.547$ & $11.479 \pm 0.525$ \\
\hline & BW & $231.293 \pm 12.016^{a}$ & $226.032 \pm 10.607^{a b}$ & $213.011 \pm 10.530^{b}$ & $229.792 \pm 16.025^{\mathrm{a}}$ & $218.091 \pm 17.670^{b}$ \\
\hline
\end{tabular}

Values followed by different alphabets differ significantly

${ }^{a, b}$ Different lowercase letters indicate a significant difference within each classification $(P \leq 0.05)$

$\mathrm{EN}, \mathrm{EW}$, and BW refer to egg number, egg weight, and bird weight, respectively

Japanese quails. Instead, a tight interaction between both factors was witnessed, in which BR line with AA genotype showed the best production values than $B R$ line with AG genotype or other genetic or non-genetic formulas. Unfortunately, no association study between IGF2 polymorphism and phenotypes traits was published in Japanese quails. Therefore, it can be stated that this study is the first report to describe such association, which pave the way for further understanding of IGF2 polymorphism in other populations with special emphasis on the critical role of p.F71 = in controlling EN and BW traits.

\section{Conclusion}

In this study, the association of polymorphisms at the $I G F 2$ gene with egg production traits in three lines of Japanese quail is described. Advent interaction of both IGF2 genotypes (AA and $\mathrm{AG}$ ) and birds line (BR, BL, and WT) in association with EG and BW was observed. Considering the IGF2 gene effect, it was found that birds with AG genotype, having the silent p.F71 = SNP, had lower EN and $\mathrm{BW}$ than birds with AA genotype. Concerning the line effect, BR line showed the most favorable production values than both BL and WT lines. Accordingly, BR line with AA genotype was highly recommended for egg production purposes. Therefore, it can be stated that the polymorphism of the IGF2 gene has the potential to be used in marker-assisted selection in Japanese quail. Because of the negative impact of p.F71 $=$ SNP on the measured traits, this study suggests confirming the absence of the p.F71 $=$ SNP before raising any Japanese quail population for large scale egg production.

\section{Abbreviations}

He: Expected heterozygosity; Ho: Observed heterozygosity; HWE: HardyWeinberg Equilibrium; IGF2: Insulin-like growth factor 2; PIC: Polymorphism information content; PCR: Polymerase chain reaction; SNP: Single nucleotide polymorphism; SSCP: Single-strand conformation polymorphism.

\section{Acknowledgements}

Not applicable.

\section{Authors' contributions}

M.B.S.A. and A.E. conceived and designed the study, D.A.A. conducted the experiments, and wrote the first draft of the manuscript, G.F. revised the manuscript, F.R. A. and T. M. A. analyzed the data. All authors approved the final draft of the manuscript. 


\section{Funding}

Not applicable.

\section{Availability of data and materials}

All data generated or analyzed during this study are included in this published article.

\section{Declarations}

\section{Ethics approval and consent to participate}

All procedures involving animals were approved by the animal care and use committee at the Al-Qasim Green University where the experiments were conducted (dated 10-21-2019, Decision No. 338).

\section{Consent for publication}

Not applicable.

\section{Competing interests}

The authors declare that they have no competing interests.

\section{Author details}

${ }^{1}$ Department of Animal Production, College of Agriculture, Al-Qasim Green University, Al-Qasim, Babil 51001, Iraq. ${ }^{2}$ Department of Animal Science, Faculty of Agriculture, Shahid Bahonar University of Kerman, Kerman, PB 76169-133, Iran.

Received: 19 April 2021 Accepted: 19 October 2021

Published online: 04 November 2021

\section{References}

1. Gecgel U, Yilmaz I, Gurcan EK, Karasu S, Dulger GC (2015) Comparison of fatty acid composition between female and male Japanese quail meats. J Chem 2015:1-8

2. Santos TC, Murakami AE, Fanhani JC, Oliveira CAL (2011) Production and reproduction of egg- and meat-type quails reared in different group sizes. Braz J Poultry Sci 13:9-14

3. Santhi D, Kalaikannan A (2017) Japanese quail (Coturnix coturnix japonica) meat: characteristics and value addition. Worlds Poult Sci J 73:337-344

4. El-Bayomi KM, El-Tarabany MS, Asr MAF, Awad A, Roushdy SM (2016) Detection of SNPs in growth hormone and insulin like growth factor genes in two divergently selected lines of Japanese quail. Jpn J Vet Res 64:S53-S57

5. Jeke A, Phiri C, Chitindingu K, Taru P (2018) Ethnomedicinal use and pharmacological potential of Japanese quail (Coturnix coturnix japonica) birds` meat and eggs, and its potential implications on wild quail conservation in Zimbabwe: A review. Cogent Food Agric 4:1507305

6. Rasouli Z, Zerehdaran S, Azari MA, Shargh MS (2013) Genetic polymorphism of the CAPN1 gene is associated with meat quality traits in Japanese quail. Br Poult Sci 54:171-175

7. Nasirifar E, Talebi M, Esmailizadeh A, Askari N, Sohrabi SS, Moradian H (2018) Genetic variability in growth hormone gene and association between restriction fragment length polymorphisms (RFLP) patterns and quantitative variation of live weight, carcass, behaviour, heterophil and lymphocyte traits in Japanese quails. Iran J Appl Anim Sci 8:147-152

8. Ahmadi M, Esmailizadeh AK, Ayatollahi Mehrgardi A, Nasirifar E (2014) Linkage analysis of microsatellite markers on chromosome 5 in an F2 population of Japanese quail to identify quantitative trait loci affecting carcass traits. J Livest Sci Technol 2:32-38

9. Charati $\mathrm{H}$, Esmailizadeh AK, Jabbari Ori R, Moradian $\mathrm{H}$, Ayatollahi Mehrgardi A (2014) Detection of quantitative trait loci affecting carcass traits and internal organs on chromosome 3 in an F2 intercross of Japanese quail. Anim Sci Pap Rep 32:369-383

10. Iranmanesh M, Esmailizadeh A, Mohammad Abadi MR, Zand E, Mokhtar S, Wu D (2016) A molecular genome scan to identify DNA segments associated with live weight in Japanese quail. Mol Bio Rep 43:1267-1272

11. Nasirifar E, Talebi M, Esmailizadeh AK, Moradian H, Sohrabi SS, Askari N (2016) A chromosome-wide QTL mapping on chromosome 2 to identify loci affecting live weight and carcass traits in F2 population of Japanese quail. Czech J Anim Sci 61:290-297

12. Chao W, D'Amore PA (2008) IGF2: epigenetic regulation and role in development and disease. Cytokine Growth Factor Rev 19:111-120

13. Gicquel C, Le Bouc Y (2006) Hormonal regulation of fetal growth. Horm Res 65:28-33

14. Beccavin C, Chevalier B, Cogburn LA, Simon J, Duclos MJ (2001) Insulinlike growth factors and body growth in chickens divergently selected for high or low growth rate. J Endocrinol 168:297-306

15. Yan L, Fang X, Liu Y, Elzo MA, Zhang C, Chen H (2017) Exploring the genetic variants of insulin-like growth factor II gene and their associations with two production traits in Langshan chicken. J Appl Anim Res 45:60-63

16. Romao JM, Moraes TGV, Teixeira RSC, Buxade CC, Cardoso WM (2009) Incubation of Japanese quail eggs at different temperatures: hatchability, hatch weight, hatch time and embryonic mortality. Arch Vet Sci 14:155-162

17. Al-Kafajy FR, Al-Shuhaib MBS, Al-Jashami GS, Al-Thuwaini TM (2018) Comparison of three lines of Japanese quails revealed a remarkable role of plumage color in the productivity performance determination. J World's Poult Res 8:111-119

18. Al-Shuhaib MBS (2017) A Universal, rapid, and inexpensive method for genomic DNA isolation from the whole blood of mammals and birds. J Genet 96:171-176

19. Al-Shuhaib MBS (2018) A minimum requirements method to isolate large quantities of highly purified DNA from one drop of poultry blood. J Genet 97:e87-e94

20. Ye J, Coulouris G, Zaretskaya I, Cutcutache I, Rozen S, Madden T (2012) Primer-BLAST: A tool to design target-specific primers for polymerase chain reaction. BMC Bioinformatics 13:134

21. Al-Shuhaib MBS, Al-Thuwaini TM, Fadhil IA, Aljobouri TRS (2019) GHRL gene-based genotyping of ovine and caprine breeds reveals highly polymorphic intronic sequences in Awassi sheep with several RNA motifs. J Genet Eng Biotechnol 17:3

22. Byun SO, Fang Q, Zhou H, Hickford JGH (2009) An effective method for silver-staining DNA in large numbers of polyacrylamide gels. Anal Biochem 385:174-175

23. Yeh FC, Yang RC (1999) POPGENE version 1.31, Microsoft window-based freeware for population genetic analysis. University of Alberta and Tim Boyle, Centre for International Forestry Research.

24. Botstein D, White RL, Skolnick M, Davis RW (1980) Construction of a genetic linkage map in man using restriction fragment length polymorphisms. Am J Hum Genet 32:314-331

25. Ye Q, Xu J, Gao X, Ouyang H, Luo W, Nie Q (2017) Associations of IGF2 and DRD2 polymorphisms with laying traits in Muscovy duck. PeerJ 5:e4083

26. Pu YJ, Wu Y, Xu XJ, Du JP, Gong YZ (2016) Association of VIPR-1 gene polymorphisms and haplotypes with egg production in laying quails. J Zhejiang Univ Sci B 17:591-596

27. Ahmed LS, Al-Barzinji YMS (2020) Three candidate genes and its association with quantitative variation of egg production traits of local quails by using PCR-RFLP. Iraqi J Agric Sci 51:124-131

28. Al-Shuhaib MBS, Al-Kafajy FR, Al-Jashami GS (2020) A computational approach for explaining the effect of the prl gene polymorphism on prolactin structure and biological activity in Japanese quails. Anim Biotechnol 29:1-9

29. Komar AA (2007) Silent SNPs: impact on gene function and phenotype. Pharmacogenomics 8:1075-1080

30. Im EH, Hahn Y, Choi SS (2018) Functional relevance of synonymous alleles reflected in allele rareness in the population. Genomics 110:347-354

31. Sukhumsirichart W (2018) Polymorphisms: Genetic diversity and disease susceptibility, 3-24. https://doi.org/10.5772/intechopen.76728

32. Kirchner S, Cai Z, Rauscher R, Kastelic N, Anding M, Czech A et al (2017) Alteration of protein function by a silent polymorphism linked to tRNA abundance. PLoS Biol 15:e2000779

33. Bagh J, Panigrahi B, Panda N, Pradhan CR, Mallik BK, Majhi B, Rout SS (2016) Body weight, egg production, and egg quality traits of gray, brown, and white varieties of Japanese quail (Coturnix coturnix japonica) in coastal climatic condition of Odisha. Vet world 9:832-836

34. Minvielle F, Gourichon D, Moussu C (2005) Two new plumage mutations in the Japanese quail: "curly" feather and "rusty" plumage. BMC Genet 6:14 
35. Minvielle F, Hirigoyen E, Boulay M (1999) Associated effects of the Roux plumage color mutation on growth, carcass traits egg production and reproduction of Japanese quail. Poult Sci 78:1479-1484

36. Recoquillay J, Leterrier C, Calandreau L, Bertin A, Pitel F, Gourichon D et al (2013) Evidence of phenotypic and genetic relationships between sociality, emotional reactivity and production traits in Japanese quail. PLoS ONE 8:e82157

\section{Publisher's Note}

Springer Nature remains neutral with regard to jurisdictional claims in published maps and institutional affiliations.

\section{Submit your manuscript to a SpringerOpen ${ }^{\odot}$ journal and benefit from:}

- Convenient online submission

- Rigorous peer review

- Open access: articles freely available online

- High visibility within the field

- Retaining the copyright to your article

Submit your next manuscript at $\boldsymbol{\nabla}$ springeropen.com 